\title{
Parent Group Education to ENABLE “Barrio” Parents
}

\section{Herman Curiel}

\begin{abstract}
This paper describes a 1960s "War on Poverty" parent group education program that brought together three national private voluntary agencies with federal funding by the Office of Economic Opportunity (OEO). Project ENABLE (Education Neighborhood Action for a Better Living Environment) sought to direct professional efforts to help/empower the poor and societal members of ethnic minority groups. Group education as a preventive modality was used to strengthen parents' problem solving skills in their roles both as parents and as community leaders. The author describes his group leadership role together with that of the indigenous case aides who helped direct/enable the collective power of a group of poor Spanish speaking Mexican origin families living in barrios (neighborhoods) of a major metropolitan southern city. Project ENABLE embraced a strengths-based perspective characteristic of social work's historical empowerment traditions. Despite its brief existence, Project ENABLE functioned as a demonstration program in 62 communities across the United States. Ironically, its prevention focus and demonstration nature served to undermine its ability to compete with other OEO initiatives like Head Start and job training programs. The author cites a combination of historical and logistic factors that contributed to the short life and ultimate demise of a once promising outreach program.
\end{abstract}

Keywords: Empowerment, enable, war on poverty, Mexican-origin, indigenous case aide, promotora, Economic Opportunity Act, Whitney Young, Blacks, outreach, barrio

Created during the mid 1960s, Project ENABLE (Education, Neighborhood Action for a Better Living Environment) was one of the Federal programs of the so-called War on Poverty. The project was envisioned as an outreach prevention demonstration model designed to serve impoverished families living in minority communities through a collaborative strategy that utilized private social agencies supported with public funding. Project ENABLE was a partnership initiative between the Child Study Association of America (CSA), The National Urban League (NUL) and The Family Service Association of America (FSAA) with funding from the U.S. Office of Economic Opportunity (OEO). The Economic Opportunity Act was part of President Lyndon Baines Johnson's social and economic initiatives known as the "Great Society" in which we were waging a "War on Poverty." Sargent Shriver, a key architect of the Economic Opportunity Act served as director of OEO until 1969. Although the architects of Project ENABLE did not use the term "empowerment," it was the aim of the collective initiative to empower families living in poverty. Simon (1994) rightly reminds us that the profession of social work has a long history of empowerment traditions. The empowerment perspective, she says, seeks to help clients draw on personal, interpersonal and political strengths to enable them to gain greater control, individually and collectively, over their environment. Despite its brief existence, this is exactly what Project ENABLE hoped to achieve. It utilized nonclient groups to develop and strengthen the participants’ parental coping skills, and the

Herman Curiel, Ph.D., is a Professor in the Anne \& Henry Zarrow School of Social Work at the University of Oklahoma in Norman, OK.

Copyright (C) 2014 Advances in Social Work Vol. 15 No. 1 (Spring 2014), 51-62 
leadership skills needed to solve neighborhood concerns. The formative challenges for leaders of this innovative demonstration project were significant. The basic processes of the empowerment perspective are used to analyze Project ENABLE within the context of its developmental stages. The author concludes by relating a combination of historical and logistical factors that contributed to the relatively short life span of Project ENABLE.

\section{Formative}

Before the birth of Project ENABLE in 1961, leaders from the Child Study Association of America (CAA) and Family Service Association of America (FSAA) had begun collaborative discussions that led to a three year training project funded by the National Institute of Mental Health. The purpose of the project was to train FSAA case workers in group-discussion techniques for parent education. Family life education was envisioned as a preventive strategy to forestall family breakdown (Morris, 2004). The success of this training program led to further interest and discussions by Oscar Rabinowitz (CSAA), Project Director and Ellen P. Manser, Project Coordinator for FSAA on ways to extend training to many more agencies through utilization of people already trained in the NIMH project (Manser, 1968). In 1965 leaders from FSAA and the Child Study Association proposed a joint venture with leaders from the National Urban League to use the family life education model to reach minority families with OEO funds. National Urban League staff had had previous inquiries on the use of the family life education methodology with CSAA and FSAA nationally and locally at various times.

The more militant members of the War on Poverty, particularly those working within the Community Action Programs, were viewed as advocates for the poor seeking to change bureaucracies that were seen as barriers or were not consumer user friendly. Voluntary agencies were not immune from criticism. Richard Cloward, professor at Columbia University, maintained that social welfare institutions and the people who staffed them were in many instances barriers, rather than aids, to the progress of poor people. In 1963 he singled out voluntary-sector "family service" agencies as examples of how the poor had been abandoned by the institutions intended to serve them (Cloward, 1963).

Project ENABLE Director, Ellen Manser (1968) describes the back and forth leadership communication challenges between public (OEO) administration levels and private agencies. Federal funds for projects were funneled through state, regional and local Community Action Agencies (CAA) which added additional hurdles for Family Service, Child Study \& National Urban League administrators. In 1965, conducting agency meetings across locations was frustrating for administrators who did not have access to cell phones, computers, e-mail, faxes or other modern day communication tools. After extensive negotiations between partner agencies and the new OEO, funding for Project ENABLE was approved September 10, 1965 in Washington (Manser, 1968). In retrospect, the creation of these partnerships by Whitney M. Young, Jr., Clark W. Blackburn and Alfred D. Buchmueller and others represented a significant political and logistics achievement. Whitney M. Young was Executive Director of the National Urban League, Inc., Alfred Buchmueller, was executive Director of the Child Study Association 
of America and Clark W. Blackburn was General Director of Family Service Association of America. Critics of the partnership initiative questioned the competence of private agencies serving the poor. Private social service agencies, such as FSAA and CSAA, were viewed by critics as elite white agencies with limited experience working with the poor. Historically, they had established a reputation based primarily on serving middle class families and professional knowledge building. Private agencies attracted a large number of new social work graduates seeking continued professional mentorships. The National Urban League, although a private agency, was viewed less critically due to its long history serving Black families in their communities. The War on Poverty presented opportunities for private agencies to acquire public funding to test innovative group strategies to work with the "hard to reach" poor families. The leadership of private agencies expressed fears as well. Board members were concerned about administrative control and possible consequences of accepting public funding and engaging in social action activities. The formative leadership challenges for FSAA and partner initiative agencies were obviously considerable.

\section{On Becoming a Group Leader}

In 1966 there was no National Urban League affiliate in Houston, thus requiring local trainees to learn group leadership roles for conducting both parent and community education (community organization) groups. This was fortunate for me because I was assigned a seasoned mentor in Felton Alexander. Felton, a MSW staff member for the Dallas, Texas National Urban League office and regional community organization trainer became my community organization supervisor. In addition to Felton, Alline Del Valle, another MSW, supervised my parent group education learning. She directed the Family Life Education program at my home agency in addition to being parent education regional staff-trainer for Project ENABLE. Alline Del Valle was a gifted group leader who loved teaching that role to others. Seemingly, she could do anything with groups and group members loved her instantly. Her group interaction style reminded me of Virginia Satir's work with families (Satir, 1976). Alline frequently expressed pride in my group work efforts on behalf of Spanish speaking parents. I still picture her reaching for a cigarette as she eagerly arranged her chair to listen to my weekly group session report. In addition to my Project ENABLE roles I had a counseling caseload that required additional supervision. Before my weekly supervision conference I had to record and submit case process recording notes. Process recordings, for readers unfamiliar with this form of clinical training, read like a play script. They were exceedingly labor intensive for both supervisee and supervisor. At the time, I shared my peers' dislike of process recording, but in retrospect I have learned to appreciate its educational value and how it contributed to my increased self-awareness. Ruth Searls, a MSW from Smith College with many years of clinical social work experience, supervised my direct client work. Ruth's supervision, like Alline's, was supportive and growth oriented. As I reflect on my extensive supervision I feel privileged to have had so much support. My supervision was a formative process that definitely contributed to my successful work with agency clients and group leadership work in Project ENABLE. What is not known is whether similar supervision was missing for Project colleagues at other sites. 


\section{Innovative Outreach}

The use of "indigenous" neighborhood case aides was a significant innovative outreach strategy. Neighborhood case aides with "on the job" training and on-going close supervision were key contributors to successful projects. Being neighborhood residents, the case aides had the kind of knowledge and personal connections to neighbor residents the social workers typically lacked. The case aides solicited potential group participants at local venues such as churches or by door to door neighborhood contacts. The social worker, with the help of the case aides identified community needs. The aides found local meeting space and made arrangements for child care at the neighborhood sites.

The social worker, on the other hand, had social service resource knowledge the social work case aide lacked. Together their shared knowledge increased their power as helpers and as a team. The role of the case aides was similar to that of promotoras (promoters) in health care prevention programs in Mexico and in some U.S.-Mexico border states (see Curiel, 2013 on promotoras). The indigenous case aides extended the group leader's credibility with "hard to reach" families most of whom had little experience with professional social workers. These families were mainly from ethnic or racial minority populations that traditionally have had trust issues with non-minority members of the larger society and little or no experience with professional social workers. The social work aides symbolically became a psychological bridge for trust building between the professional social worker and parent group members and/or their community counterparts.

\section{Training Group Leaders}

Training consisted of social workers attending two regional one week training sessions, one held in April 1966 before the project began, and a second in July 1966 timed to coincide with the completion of the first eight week series of ENABLE groups. Whitney Young, Executive Director of National Urban League, was present for the initial project orientation. He described the initiative goals and the role expectations of trainees and indigenous case aides. He introduced the program area expert-trainers who in turn described their respective background experiences and project roles. Alline del Valle, parent group educator, demonstrated group leadership techniques by leading a live parent education group. Felton Alexander, a community organization expert, explained role of community organizer and principals of community organization plus techniques for forming and maintaining groups. Dr. Aaron Rosenblatt, Project research director, described purpose of Project ENABLE research and explained how to train and supervise social work aides whose role included the collection of data during home visits. His handouts included a research manual, "Supervising the research interviewing of social work aides" and questionnaire forms that would guide data collection. His book, Attendance and attitude change: A study of 301 Project ENABLE groups (Rosenblatt, 1968) describes data and results by regional sites. 


\section{Race Climate in the 1960s}

Recruitment of Project ENABLE (1966-1967) parent groups occurred at a time when race relations between blacks and whites were at a boiling point. President John F. Kennedy's response to national violence and his desire to end racial discrimination was the focus of his June 11, 1963 Civil Rights Address. His assassination on November $22^{\text {nd }}$ of that same year represented a serious symbolic and substantive blow to the civil rights movement, but did serve to bring about the nation's resolve for change. During the early 1960s the city of Houston was in the process of desegregating public facilities that had barred blacks from white establishments such as hotels, theaters, restaurants, public schools, colleges, parks, jails, and hospitals (Scott, 1967). Kennedy's death undoubtedly helped Lyndon B. Johnson achieve the landmark passage of the Civil Rights Act of 1964 as well as the Voting Rights Act of 1965. The August 11-17, 1965 Watts riots in South Central Los Angeles was one more manifestation of the tense racial climate. These events, occurring in close time proximity to the introduction of Project ENABLE, likely had an effect on team work at some sites. However, as Morris (2004) notes, the African American and Mexican American teams worked closely and smoothly in Houston. While this was true with respect to team relationships in general, recruitment and attendance were a consistent problem for the Houston Black community team leader. There was an unanticipated initial leadership change for the Black community team. The original African-American group leader learned she was pregnant during the group leadership training phase. Fortunately, she was able to hire two indigenous African-American case aids before vacating her position. A non-Hispanic White social worker with extensive group work practice experience assumed the vacated leadership role with the help of case aides hired by her predecessor. In a recent telephone interview with the group leader's successor (M. Kleymeyer, personal correspondence, August 20, 2013) conducted for purpose of this manuscript, said: "Being white, without a doubt, introduced trust issues for neighborhood parents that her case aides could not bridge.” Her case aides were not able to recruit members for a single group. However, they did identify a small number of families for whom help was provided directly by her case aides with her direction. As indicated earlier, the parent recruitment phase of Project ENABLE, which occurred during a national period of racial crisis, almost certainly contributed to group recruitment and retention problems particularly at sites where racial differences existed between group leaders and the indigenous community.

\section{Reaching Barrio Families}

Apart from the national racial crisis, whenever the characteristics of the group leader, the case aides, and the community were similar, the group was free to pursue the intended learning objectives of Project ENABLE. Auerback (1968) contended that while the general field of parent education was identified as a middle class movement, its methodology, as evident in Project ENABLE, could be applied to virtually all socioeconomic levels and educational backgrounds. Project ENABLE sought to give parents an opportunity to discuss family issues and community concerns with a social worker either directly or through the case aides. Del Valle and Alexander (1967) maintained that the basic philosophy of Project ENABLE was to help poor people change 
their environment, not to simply adjust to a miserable set of environmental circumstances (p. 637). Manser (1968), the Director for Project ENABLE, noted that the bulk of participants in the program were among the poorest in society, generally falling one level above the lowest category on Hollingshead's classification of social status. The parent groups that were the focus of this barrio community were Spanish speaking Mexicanorigin Hispanics. The term "barrio," Spanish for neighborhood, is generally analogous to the concept of "ghetto" as it appears in the literature for describing inhabitants in an ethnic poverty community.

I was raised by a non-English speaking grandmother in a poor Mexican barrio where my early formal education began as a non-English speaking student. I was fortunate to have had many caring non-Hispanic white teachers who cared and were patient with my learning English. I must have had some instruction in Spanish because I was able to read and write in Spanish by the time I enrolled in middle school. Knowing Spanish and sharing a similar ethnic-cultural world view with the case aides and parent group members was a definite advantage. As a bilingual group leader, I was able to conduct sessions for both Spanish speaking groups as well as those comprised of both Spanish and English speaking members.

The initial orientation meetings for Project ENABLE groups included information on its purpose as well as description of the discussion format that would be employed during the ninety-minute sessions over the eight weeks. The various roles of key actors, the discussion leader and the social work case aides were explained. The research need for informed consent to permit case aides to collect information to evaluate project outcomes was also explained.

All the parent meetings were held during the evening hours in local neighborhood facilities with child care and transportation provided. The composition of the groups consisted primarily of Mexican origin Spanish speaking mothers. Fathers were more likely to be present in the groups formed to address community concerns. Group member attrition was not a significant problem at any of the five neighborhood group sites. One multi-ethnic group was held at a public integrated housing project. This diverse group of twenty mothers included three sub-groups represented in almost equal numbers, women of Mexican origin who spoke only Spanish, non-Hispanic White women, and Black women who were new to integrated housing.

Given the bilingual composition of this group, the leader served as interpreter for both the Spanish and English speaking participants. Again, member drop-outs were rare and no obvious conflict among the subgroups was observed.

The term "parent education" is often used interchangeably with "family life education" (Auerback, 1967). In this context, parent education is viewed as only one aspect of family life education. Project ENABLE utilized principles of parent education as articulated by Auerback (1967). The role of the leader was not to lecture, but to facilitate discussion. During the initial session, themes based on expressed parental concerns or interests were identified for subsequent topics for discussion. These parent discussion groups were used to help parents talk about child rearing concerns or family problem solving approaches. Other discussion groups were formed to help parents 
develop problem solving skills to improve quality of life in their neighborhood communities (physical environments). The acronym ENABLE meant just that - to enable or empower the participants. Simon (1994) in her book, The Empowerment Tradition in American Social Work: A History, identifies five basic processes associated with the empowerment approach: (1) constructing collaborative client partnerships; (2) emphasizing client strengths; (3) focusing on social and physical environments; (4) recognizing client-group rights, needs and responsibilities; and, (5) directing professional energies toward helping historically disempowered groups and their members. In the following section the Project ENABLE processes are examined within the context of these five basic processes as identified by Simon (1994), with a primary emphasis on the first three.

\section{(1) Constructing Collaborative Partnerships}

To achieve collaborative partnerships with prospective parent group members, we first had to create and function as a collaborative team. Both case aides were SpanishEnglish bilingual parents themselves with a high school education. Both had a history of doing volunteer work in their respective communities, and after their initial training, readily identified with the team concept. I quickly learned to appreciate their indigenous skills for recruiting group members and collecting data during home visits as well as their interpersonal skills for relating to members between meetings. Weekly team meetings were used to exchange information on group member needs and progress on tasks such as acquiring meeting space and data collection. It was through the case aides that I was able to gain the trust of poor families who had little or no experience with professional social workers. While the impoverished background that characterized my formative years mirrored that of many of the participants, my subsequent professional education created a social distance characteristic of professional care providers who work with clients from impoverished backgrounds. In addition, since virtually all of the participants were female, my gender difference could have potentially introduced trust issues with male family members if I were to visit homes during the father's absence.

The inclusion on the team of female case aides who had had similar life experiences to group members proved to be an important factor in gaining the parents' trust. During home visits, and with the permission of the parents, the case aides were able to explore in depth many of the specific family needs or concerns that were part of the group identified general themes discussed during the weekly team meetings.

The commitment to the team philosophy was evident in the level of the case aides' excitement during weekly team supervision meetings. I suspect this collaborative spirit contributed significantly to our continued success with respect to the high level of retention among group members.

\section{(2) Strengths Emphasis}

The group paradigm employed in Project ENABLE intentionally placed primary emphasis on the parents' coping strengths. There were no taboo discussion subjects and all ideas were found to have merit. Participants were not viewed as clients; they were 
voluntary group members seeking to learn how to improve their parenting skills. Despite their limited formal education and the crippling conditions of poverty that enveloped their lives, the innate resilience of these parents was readily evident in their day-to-day coping skills. Project ENABLE aimed to help poor families help themselves. The "hard to reach,” target population of Project ENABLE were poor ethnic/racial minority parents and families. The use of indigenous case aides helped poor families overcome their trust barriers with the social workers, which in turn ultimately helped facilitate the social worker's efforts on behalf of the "hard to reach" poor.

\section{(3) Persons in their Environment}

Project ENABLE's dual goal was to help members as parents and as change agents in the context of their neighborhood environments. As indicated earlier, the focus of the parent discussion groups was to help parents become more effective in their role as parents. When members in the parent group expressed a community concern of mutual interest, the group leader would typically explore their interest in forming a new group to address the issues engendered in the expressed concern. The existing group would continue with its focus on parenting related issues. The new group with a macro problem solving focus would meet separately and at a different time. The macro-focused groups frequently included males who had been absent in the parent education groups.

According to Johnson and Johnson (2013), problem solving is the process of finding an answer to a perceived difficulty. The six steps to problem solving identified by them, paraphrased here, characterized the process of community focus group meetings: (1) problem identification, (2) contextual issues, (3) alternative strategies, (4) pro and con merits of alternative potential strategies, (5) implementing the most appropriate strategy, and (6) evaluating outcomes. The following actual community case illustrates the problem solving process:

Case Example: A community action group was formed motivated by parental anger with a neighborhood park manager who routinely called police to report their children for alleged use of profane language. The group identified the problem as the park manager's unwillingness or inability to handle the children's behavior, or at least involve them before escalating the problem by invoking police intervention. The subsequent group process explored the scope of the problem, including the number of such incidents in which children were sent to juvenile detention and the number of parental attempts at multiple levels to resolve or call attention to the problem. Group members claimed the park manager and her immediate supervisor were not responsive to their repeated complaints. After several group meetings, a range of potential strategies were explored, including a possible park boycott, a group meeting with both the park manager and her supervisor, publicizing the problem in the public media, and scheduling a meeting with the mayor and City Council. The group ultimately decided a joint group meeting with the Director of Parks \& Recreation and local park manager would be the most propitious strategy. With the group's permission, the group leader met with the Director of Parks \& Recreation to convey the substance of the group's complaint and to schedule a meeting. In 
anticipation of the actual meeting with the Director and park manager, the group leader helped the members prepare for the experience by engaging them in a role play. Before meeting with the Park Director and park manager, some group members expressed doubts that the meeting would ever take place as well as concern as to what might happen if it actually did. Not only did the meeting with the Director of Parks and Recreation take place, but it proved to be a pleasant and empowering experience for the group members. Two unexpected outcomes occurred. One was the resignation of the park manager with whom they had had so many negative prior experiences, and the other was the Director's invitation to have the group screen applicants and ultimately approve the final candidate for the new park manager position.

\section{(4) Recognizing Client-Group Rights, Needs, and Responsibilities}

The Park Director's willingness to involve the group members in the decisionmaking process involving the selection of the new park manager gave meaning and substance to Simon's (1994) fourth empowerment principle, namely the "recognition of client rights, needs and responsibilities." It not only served to affirm them as individuals capable of making a meaningful difference in their own lives, but also helped allay some of the debilitating cynicism that tended to characterize their attitudes toward the existing power structure. It provided a compelling argument that constructive change was indeed possible when they exercised their individual and collective right to act responsibly on their own behalf. Part of the challenge in working with the so-called "hard to reach" is that many of them have little or no hope that meaningful change is even possible. They simply had no prior life experiences that give them reason to believe that the investment of time and energy in trying to change the status quo would make any difference. As noted earlier, that very attitude had been expressed in one of the community group sessions. Following their success with this particular issue there was a renewed sense of hope and optimism that laid a beginning foundation for the possibility of meaningful future systemic changes.

\section{(5) Directing Professional Energies toward Helping Historically Disempowered Groups and their Members}

Without the careful planning and subsequent training of the members of the Project ENABLE team, it is unlikely that any of the benefits accrued by this group experience would ever have been realized. It was only because of the systematic training that preceded the actual group discussions, including the commitment to a collaborative team philosophy, that it was possible for the parents to gain the courage necessary to act on their own behalf. To the extent to which this is true, it confirms the validity of Simon's fifth empowerment process that emphasizes the importance of professional training as a necessary prerequisite to facilitate the group problem solving learning process.

\section{Summary and Conclusion}

Project ENABLE, a 1960s War on Poverty program was a short lived outreach prevention demonstration effort designed to reach poor communities. It became a model 
for private/public joint efforts. Having a group leader and social work case aides that shared the groups' cultural world view contributed to positive outcomes for one successful site. Although the concept of empowerment was not in the vocabulary of Project ENABLE, the processes of the empowerment approach later identified by Simon (1994) were present in the actual objectives of Project ENABLE. Group members in Project ENABLE were not treated as clients, but as free agents capable of shaping and controlling their own lives. Group members came from historically underrepresented population groups. The partnership initiative was an effort to direct professional energies to help, ENABLE or empower members of societal groups who had historically experienced societal oppression and discrimination. The use of indigenous case aides was innovative for its time and proved to be a key contributor to successful outreach efforts.

The program was short lived because it was judged to be a low priority compared to job-training and other educational programs like Head Start that were simultaneously competing for limited Federal funds. The multiple funding level decision making structure was problematic and the short term funding cycle proved to be short sighted. New programs require more than one year for stable implementation. It takes time to hire, train and implement staff program roles across multiple agencies. The contentious climate that existed between public and private agencies did not help. The timing of the project in the mid 1960s, when racial tensions were at a peak, contributed to recruitment and retention problems in some sites. Evidence of the program's successful operation in one site has been presented. On this basis, the author submits that the fundamental concepts and principles that informed the original Project ENABLE experiment merits our serious re-consideration.

\section{Implications of Project ENABLE for Contemporary Practice}

As indicated above, the fundamental concepts and principles that informed Project ENABLE merit re-consideration for working with today's impoverished minority populations. Preventing social problems is always challenging and a desirable objective for the social work profession. All parents regardless of social class will need help with

child rearing and parenting concerns. Agencies continue to be challenged with reaching populations that are labeled "hard to reach." To prepare students to engage in this kind of preventative group work, social work schools need to provide content that will prepare students to work with groups, including community action groups. The training and use of indigenous paraprofessionals with close supervision is an effective means to extend the social worker's reach to clients who fear and have little knowledge of professional helping. Given the increasing growth of the Hispanic population and limited number of social workers fluent in Spanish, the use of bilingual Spanish speaking indigenous paraprofessionals offers a potential source to extend the power of social work services to non-English speaking clients.

\section{References}

Auerbach, A. B., \& The Child Study Association of America (1968). Parents learn through discussion: Principles and practices of parent group education. New York, NY: John Wiley \& Sons Inc. 
Birnbaum, M. L., \& Jones, C. H. (1967). Activities of the social work aides. Journal of Social Casework, 40, 626-632

Birnbaum, M. L., Harm, M. G., \& Ortof, S. B. (1967). The content for training in project enable. New York, NY: Family Service Association of America.

Civil Rights Act of 1964, Teaching with documents: The civil rights Act of 1964 \& Equal Employment Opportunity Commission. College Park, MD: National Archives and Records Administration. Retrieved from http://www.archives.gov/education/lessons/civil-rights-act/

Cloward, R. A. (1963). Social class and private social agencies. In Council on Social Work Education, Eleventh Annual Program Meeting, Proceedings (pp. 123-137). New York: Council on Social Work Education.

Curiel, H. (2013). Latinos \& Latinas: Mexicans. In T. Mizrahi \& L. E. Davis (Eds.), Encyclopedia of social work (20 ${ }^{\text {th }}$ ed., pp. 48-54). Washington, DC: Oxford University Press

Del Valle, A., \& Alexander, F. (1967). Effects of the project enable on family service agencies and urban league. Journal of Social Casework, 40, 637.

Gale Encyclopedia of US History. (2006). Office of Economic Opportunity, Encyclopedia of American History. The Gale Group, Inc. Retrieved from http://www.answers.com/topic/oeo\#ixzz2Z2jqBwy2

Johnson, D. W., \& Johnson, F. P. (2013). Joining together: Group theory and group skills. Boston, MA: Pearson Education, Inc.

Manser, E. P. (1968). Project ENABLE: What happened? New York: Family Service Association of America, OEO, CAP Grant No. 9064.

Morris, A. (2004). The voluntary sector's war on poverty. The Journal of Policy History, 16(4), 275-305.

Rosenblatt, A. (1968). Attendance and attitude change: A study of 301 project enable groups. New York, NY: Family Service Association of America.

Satir, V. (1976). Making contact. Millbrae, CA: Celestial Arts.

Scott, A. (1967). Twenty-five years of opinion on integration in Texas. Southwestern Social Science Quarterly, 48(2), 155-163.

Simon, B. L. (1994). The empowerment tradition in American Social Work: A history. New York: Colombia University Press.

Voting Rights Act of 1965, America’s historical documents. College Park, MD: National Archives and Records Administration. Retrieved from http://www.archives.gov/historicaldocs/document.html?doc=18\&title.raw=Voting\%20Rights\%20Act

www.history.com. This day in history. Aug 11, 1965: Watts riot begins. Retrieved from http://www.history.com/this-day-in-history/watts-riot-begins 


\section{Author note}

Address correspondence to: Herman Curiel, Ph.D., Professor, University of Oklahoma School of Social Work, 700 Elm Avenue, Norman, OK 73019. Email: hcuriel@ou.edu

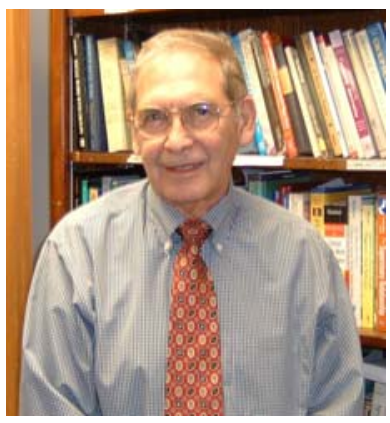

Herman Curiel was Co-Principal Investigator (2000-2006), with the US/Mexico Border Health Evaluation Center, a Health Resources \& Services Administration's (HRSA) SPNS Project. He is Professor at the Anne \& Henry Zarrow School of Social Work, University of Oklahoma. His research and publications focus primarily on minority issues with emphasis on Hispanic/Latino population concerns related to education, health and HIV/AIDS. In 2005 he was the recipient of the "Social Work Educator" award by the Social Work School's Board of Visitors. In 2011 he was named an "NASW Social Work Pioneer" by NASW's Foundation. He has served on the editorial board of Social Work, and as consulting editor for the Journal of Social Work Education and the Journal of HIV/AIDS \& Social Services. His publications can be found at http://socialwork.ou.edu/ 